\title{
Treatment of multibacillary leprosy with a regimen of 13 weeks duration
}

\author{
S R PATTYN, ${ }^{*}$ G GROENEN, $\dagger$ L JANSSENS, $\ddagger$ \\ L KUYKENS \& \& L B MPUTU† \\ *University of Antwerp and Institute of Tropical Medicine, Antwerp, \\ Belgium; $\dagger$ Bureau National de la Lépre, Kinshasa, Zaire; $\ddagger$ Formerly \\ Museniene Hospital, Zaire; §Damien Foundation Kisangani, Zaire
}

\author{
Accepted for publication 26 July 1981
}

\begin{abstract}
Summary In a prospective study 559 multibacillary patients in Zaire were treated for 13 weeks with twice weekly rifampicin $(600 \mathrm{mg})$ and daily ethionamide $(500 \mathrm{mg})$ and dapsone $(100 \mathrm{mg}), 13-\mathrm{RED}$, or clofazimine $(100 \mathrm{mg}), 13-\mathrm{REC}$. The patients were followed for a total of 1418 person years, mean 3.2 years. The incidence of hepatitis was $3.3 \%$. The incidence of relapses was $0 \cdot 28$ per 100 person years. Relapses were due to drug-sensitive organisms.

In patients who received the same drug regimens but with a reduced dosage of ethionamide to $5 \mathrm{mg} / \mathrm{k}$ bodyweight, the incidence of hepatitis was significantly lower but the relapse rate was $7 \cdot 8$ per 100 person years of follow-up in the RED group, no relapses were diagnosed in the REC group.

It is concluded that by the use of potent antileprosy drugs in suitable combinations and dosages, it will be possible to shorten the duration of antibacterial treatment in multibacillary leprosy to 3 months.
\end{abstract}

\section{Introduction}

Previous studies on the treatment of multibacillary leprosy evaluated the efficacy of regimens combining rifampicin (RMP), ethionamide (ETH) and either dapsone (DDS) or clofazimine (CLO) during 12 or 6 months. ${ }^{1-4}$ The conclusions from these studies were that the relapse rates after these regimens are extremely low: 0-0.06 per 100 patient years of follow-up, after a mean duration of follow-up of 5-6.1 years.

On this basis, a treatment regimen of shorter duration could be envisaged and the hepatotoxicity observed with the longer regimens ${ }^{5}$ could hopefully be reduced through a reduction of the administration of the combination of RMP and ETH. A treatment regimen of 13 weeks duration was therefore applied in patients in Zaire. 


\section{Patients and methods}

Multibacillary (MB) patients presenting at or referred to the participating centres with clinically active disease, and agreeing to stay near the centres or to be hospitalized for 13 weeks were taken into the trial. Thus all treatments were supervised.

All patients were examined clinically, neurologically and bacteriologically. A copy of the clinical file was sent to Antwerp together with a skin biopsy fixed in $10 \%$ formalin. MB leprosy was diagnosed if the bacterial index (BI) was 2 or more a t any of 3 sites from which slit-skin smears were prepared (1, earlobe and 2 skin lesions) and was confirmed by histopathology.

In the absence of complicating reactions follow-up examinations are performed yearly and are identical to those at intake. Criteria for the evaluation of therapy are: absence of active clinical lesions, decrease of the BI in skin smears and biopsies, absence of solidly staining bacilli in the biopsies, decrease of the histopathological lesions and absence of side-effects.

The neurological evolution was evaluated through comparison of the disability scores (three degree WHO scoring scale) ${ }^{6}$ and the number of hypertrophied nerves at the start of treatment and the last follow-up examination.

Patients were randomized between two treatment regimens: RMP $600 \mathrm{mg}$ twice a week, together with ETH $500 \mathrm{mg}$ and either DDS $100 \mathrm{mg}$ (13-RED) or CLO $100 \mathrm{mg}$ (13-REC) daily, for a total duration of 13 weeks. Patients previously treated with DDS monotherapy for 5 years or more and thus at risk of harbouring DDS-resistant Mycobacterium leprae received the 13-REC regimen.

Due to a misunderstanding 35 patients at the Museniene Hospital in Zaire were given a reduced dose of ETH, $5 \mathrm{mg} / \mathrm{k}$ bodyweight. The patients on this regimen are analysed separately.

Hepatitis was diagnosed clinically. Relapse was diagnosed clinically when new lesions appeared and was confirmed by an increase of at least 2 units of the BI in skin smears and biopsies with an important fraction of solidly staining bacilli. Furthermore, from 4 cases a skin biopsy on ice was brought to Antwerp for mouse footpad inoculation and sensitivity testing for the drugs the patients had been treated with. For sensitivity tests in mice, drugs were administered as follows: DDS in the mouse food at $10^{-2}, 10^{-3}, 10^{-4} \mathrm{~g} \%$, ETH in the food at $10^{-2} \mathrm{~g} \%$, CLO at $3 \cdot 10^{-3} \mathrm{~g} \%$ in the food, RMP $10 \mathrm{mg} / \mathrm{k}$ once a week by gavage, during 10 weeks. Statistical analysis was done by Student $t$-test or $\chi^{2}$ test where appropriate. Confidence limits were taken from Tabulae Scientificae. ${ }^{5}$

\section{Results}

A total of 556 patients were taken into the study: 268 in regimen 13-RED and 291 in regimen 13-REC. In the first group $49(18.3 \%)$ patients were lost to follow-up within the first year, $5(1 \cdot 8 \%)$ patients died, leaving $214(79 \cdot 8 \%)$ patients for analysis. In the second group $62(21 \cdot 3 \%)$ patients were lost to follow-up during the first year and $6(2 \%)$ patients died, leaving $220(75.6 \%)$ patients for analysis. In both groups some patients had received a single dose of $1500 \mathrm{mg} \mathrm{RMP}$ at some time between 2 and 12 months prior to the start of the present treatment: 24 in group 13-RED and 31 in group 13-REC. There were no differences between patients receiving the 13-RED or the 13-REC regimens as regards $\mathrm{BI}$, nerve involvement and disabilities. 
The mean BI at intake was 3.06 and decreased with a mean of 0.55 per year. As in previous studies ${ }^{2,3}$ all patients showed a favourable clinical evolution. Shortly after the start of therapy the clinical activity of the skin lesions subsided and continued to do so after the end of treatment. Reversal reactions during treatment were comparable in intensity and frequency with those observed with analogous treatment regimens of longer duration. $^{7}$ The treatment did not lead to an increase in disabilities nor to an increase in the number of hypertrophied nerves (results not shown).

Fourteen cases of hepatitis were diagnosed, 9 in the 13-RED and 5 in the 13-REC group, an incidence of $3 \cdot 2 \%$. The mean incubation time was 55 days, with a median of 52 days and a range of 17-84 days. There were no fatalities.

Late reversal reactions, appearing after the end of therapy, were diagnosed in 20 cases: 14 among the 13-RED group, incidence $6.5 \%$ and 6 among the 13-REC group, incidence $2 \cdot 7 \%$, this difference is not significant $(p=0.09)$. The mean interval relative to the end of antibacterial therapy was 33 months, with a range of $9-57$ months and a median of 33 months.

As shown in Table 1, the total follow-up represents 1418 person years, with a mean of $39 \cdot 7$ months. Four relapses were diagnosed, 2 among each treatment group, giving an overall incidence of 0.28 per 100 person years of follow-up, with a $95 \%$ confidence interval of $0.08-0 \cdot 99$. The intervals between the end of treatment and the diagnosis of relapse were $31,47,53$ and 58 months respectively, with a mean and median of 47 months. The original diagnoses in the relapsing patients were BL in 3 and LL in 1 patient. Two of the BL cases were new patients never treated before, the LL patient declared he had taken dapsone 3 years before for 3 months, one $\mathrm{BL}$ case was a patient relapsing after dapsone monotherapy.

In 2 of the BL patients relapse was signalled by the appearance of numerous small bright, red papules on an arm. Two $M$. leprae strains isolated from relapsing patients (both from 13-REC patients) were drug sensitive.

Among the group of 35 patients who erroneously received the lower dose of ETH, 2 died leaving 16 patients in the 13-RED group and 17 patients in the 13-REC group (Table 2). These patients have been followed for a total of 64 person years (mean 4 years) and 80 person years (mean 4.7 years) respectively. No cases of hepatitis were observed.

Table 1. Follow-up and incidence of relapses and late reversal reactions among patients treated with regimen 13RED or 13-REC

\begin{tabular}{|c|c|c|c|c|c|c|c|}
\hline \multirow{2}{*}{$\begin{array}{l}\text { Years of } \\
\text { follow-up }\end{array}$} & \multirow{2}{*}{$\begin{array}{l}\text { Number of } \\
\text { patients } \\
\text { seen }\end{array}$} & \multirow{2}{*}{$\begin{array}{l}\text { Person years } \\
\text { of follow-up } \\
\text { (cumulative) }\end{array}$} & \multirow[b]{2}{*}{ Number } & \multicolumn{3}{|c|}{ Relapses (cumulative) } & \multirow{2}{*}{$\begin{array}{l}\text { Number of } \\
\text { late reversal } \\
\text { reactions }\end{array}$} \\
\hline & & & & $\mathrm{N}$ & $\%$ & $(95 \% \mathrm{CI})$ & \\
\hline 1 & 434 & 434 & & & & & 4 \\
\hline 2 & 390 & 824 & - & & & & 6 \\
\hline 3 & 301 & 1125 & 1 & 1 & $0 \cdot 08$ & $(0 \cdot 00-0 \cdot 50)$ & 7 \\
\hline 4 & 215 & 1340 & 1 & 2 & $0 \cdot 14$ & $(0.01-0.52)$ & 1 \\
\hline 5 & 90 & 1430 & 2 & 4 & $0 \cdot 28$ & $(0.08-0.99)$ & 2 \\
\hline 6 & 6 & 1436 & - & 4 & $0 \cdot 28$ & $(0.08-0.99)$ & - \\
\hline Mean & & $3 \cdot 3$ & & & & & \\
\hline
\end{tabular}


Table 2. Follow-up and incidence of relapses a mong 33 patients treated with either regimens 13-RED or 13REC but with a reduced dose of ETH

\begin{tabular}{|c|c|c|c|c|c|c|}
\hline \multirow[b]{2}{*}{$\begin{array}{l}\text { Years of } \\
\text { follow-up }\end{array}$} & \multirow[b]{2}{*}{$\begin{array}{c}\text { Number of } \\
\text { patients seen }\end{array}$} & \multirow{2}{*}{$\begin{array}{l}\text { Person years } \\
\text { of follow-up } \\
\text { (cumulative) }\end{array}$} & \multicolumn{4}{|c|}{ Relapses } \\
\hline & & & Number & $\begin{array}{l}\text { Cumulative } \\
\text { number }\end{array}$ & $\begin{array}{c}\text { Incidence } \\
(\%)\end{array}$ & $95 \% \mathrm{CI}$ \\
\hline \multicolumn{7}{|c|}{ Regimen 13-RED } \\
\hline 1 & 16 & 16 & - & - & - & \\
\hline 2 & 16 & 32 & - & - & - & \\
\hline 3 & 13 & 45 & - & - & - & \\
\hline 4 & 13 & 58 & 5 & 5 & $8 \cdot 6$ & $2 \cdot 86-18.98$ \\
\hline 5 & 5 & 63 & - & 5 & $7 \cdot 9$ & $2 \cdot 63-17 \cdot 56$ \\
\hline 6 & 1 & 64 & - & 5 & $7 \cdot 8$ & $2 \cdot 59-17 \cdot 30$ \\
\hline \multicolumn{7}{|c|}{ Regimen 13-REC } \\
\hline 1 & 17 & 17 & - & - & - & \\
\hline 2 & 17 & 34 & - & - & - & \\
\hline 3 & 16 & 50 & - & - & - & \\
\hline 4 & 16 & 66 & - & - & - & \\
\hline 5 & 13 & 79 & - & - & - & \\
\hline 6 & 1 & 80 & - & - & - & $0-4 \cdot 51$ \\
\hline
\end{tabular}

Five relapses were diagnosed, all occurring in the 13-RED group giving a relapse rate of $7 \cdot 8$ per 100 patient years of follow-up. The difference between the RED and REC groups is significant $(p=0.036)$ as is the difference between the RED group who received a reduced dosage of ETH and the RED group who received the regular dose $\left(p<10^{-3}\right)$. The intervals between the end of therapy and the diagnosis of relapse were 39, 41, 42, 46 and 48 months with a mean of 43 months and a median of 42 months. Two $M$. leprae strains from these relapsing patients have been isolated in mice and were sensitive to the drugs the patients had received.

\section{Discussion}

Our previous studies ${ }^{1-4}$ have shown that it is possible to treat MB leprosy successfully with combined regimens of either 1 year or 6 months duration. On this basis and with the hope of reducing the toxicity of the association $\mathrm{RMP}+\mathrm{ETH}$, the present regimen of 3 months duration was studied in which ETH and DDS or CLO are administered daily, but RMP only twice weekly, thus reducing the administration of the combination RMP + ETH to twice weekly instead of daily as was the case in the previous studies. Pooling the results from the 13-RED and 13-REC treatment groups, the relapse rate was 0.28 per 100 person years of follow-up after a mean follow-up period of 3.3 years, which suggests that it is possible to treat MB leprosy within a period of 3 months. We do not think that the single dose of $1500 \mathrm{mg}$ RMP that $9 \cdot 7 \%$ of the patients received at 2 to 12 months before the start of the treatment profoundly influenced the results. Two of the 4 relapses manifested as small, bright red, papules, corresponding to what has been described by Ridley as exacerbation nodules. ${ }^{8}$

The incidence of hepatitis was only reduced to $3 \cdot 2 \%$, not statistically different from 
that in the longer duration regimens: ${ }^{5} 14 / 439$ versus $23 / 515 p: 0 \cdot 41$ ). No hepatitis was seen among the 33 patients treated with a reduced dose of ETH, the difference with the patients who received the regular dose of ETH is highly significant $(p<0.001)$ but the reduced dosage of ETH resulted in a much higher incidence of relapses in the RED combination.

The unplanned observation of the 33 patients who received a reduced dose of ETH in error clearly illustrates two other points-the necessity besides RMP, for a second bactericidal drug, of appropriate dosage, in the treatment of MB leprosy and the higher efficacy of CLO as compared with DDS in the triple combination. The mean interval between the end of treatment and the diagnosis of relapse was 45 months. Relapses were all clinically evident and confirmed by bacteriology and histopathology, no cases were detected by the laboratory before they were clinically evident. Relapses were not due to the selection of drug-resistant organisms.

The overall incidence of late reversal reactions was 1.39 per 100 patient years of follow-up and remained fairly constant. Clinicians should be well informed about this late complication, the distinction between late reversal reaction and MB relapses being easily documented by bacteriological and/or histological examination.

The main conclusion from the present study is that it is possible to cure MB leprosy by a treatment regimen of 3 months duration, provided bactericidal drugs are given in adequate dosage. With the advent of newer and more potent drugs and hopefully less sideeffects such as quinolones and/or minocycline ${ }^{9,10}$ the future of short-course treatment regimens in $\mathrm{MB}$ leprosy looks very promising.

\section{Acknowledgments}

The Damien Foundation, Brussels, Belgium, supported the work in the field and in the laboratory. The laboratory in Antwerp was also supported by the CEC, contract no. TS2-0027-B.

\section{References}

1 Onsun N, Saylan T, Pattyn SR. Combined therapy of multibacillary leprosy of 6 months duration. Lepr Rev, Suppl 3, 1986; 57: 124-6.

2 Pattyn SR, Bourland J, Grillone S, Groenen G. Combined regimens of one year duration in the treatment of multibacillary leprosy. I. Combined regimens with rifampicin administered during one year. Lepr Rev, 1989; 60: $109-17$.

3 Pattyn SR, Groenen G, Janssens L, Deverchin J, Ghys P. Combined regimens of one year duration in the treatment of multibacillary leprosy. II. Combined regimens with rifampicin administered during 6 months. Lepr Rev, 1989; 60: 118-23.

${ }^{4}$ Pattyn SR, Bourland J, Deverchin J, Ghys P, Grillone S, Janssens L, Kuykens P. Status of the multibacillary leprosy patients treated with combined regimens of one year duration, after a mean follow-up of more than 5 years. Lepr Rev, (submitted).

5 Pattyn SR, Janssens L, Bourland J, Saylan T, Davies E, Grillone S, Ferracci C. Hepatotoxicity of the combination rifampicin-ethionamide in the treatment of multibacillary leprosy. Int $J$ Lepr, 1984; 52: 1-6.

6 WHO Expert Committee on Leprosy. Fourth Report. Technical Report Series No. 459. WHO: Geneva, 1970.

7 Groenen G, Janssens L, Kyembe T, Nollet E, Coussens L, Pattyn SR. Prospective study on the relationship between intensive bactericidal therapy and leprosy patients. Int J Lepr, 1986; 54: 236-44.

8 Ridley DS. Reactions in leprosy. Lepr Rev, 1969; 40: 77-81.

9 Gelber RH. Activity of minocycline in Mycobacterium leprae infected mice. J Infect Dis, 1987; 186: $236-9$.

${ }^{10}$ Grosset JH, Ji B, Guelpa-Lauras CC, Pevvani EG, N'Deli LN. Clinical trial of pefloxacin and ofloxacin in the treatment of lepromatous leprosy. Int $J$ L pr, 1990; 58: 281-95. 


\title{
Traitement de la lèpre multibacillaire par un régime de 13 semaines
}

\author{
S R Pattyn, G Groenen, L Janssens, L Kuykens et L B Mputu
}

Résumé Lors d'une étude prospective, 559 patients multibacillaires du Zaïre furent traités pendant 13 semaines à la rifampicine $(600 \mathrm{mg})$ deux fois par semaine, à l'éthionamide $(500 \mathrm{mg})$ et à la dapsone (100 $\mathrm{mg})$ par jour, 13 RED, ou à la clofazimine $(100 \mathrm{mg}), 13-\mathrm{REC}$. Les patients furent sui vis pendant un total de 1418 années-patients, la moyenne étant de 3,3 ans. L'incidence d'hépatite était de 3,2\%. L'incidence de récidive était de 0,28 par 100 années-patients. Les récidives étaint dues à des organismes sensibles aux médicaments.

Chez les patients ayant reçu le même régime mais avec réduction de la posologie de l'éthionamide à $5 \mathrm{mg} / \mathrm{k}$ du poids corporel, l'incidence d'hépatite était nettement inférieure mais le taux de récidive était de 7,8\% par 100 années-patients dans le cas du groupe RED suivi; aucune récidive ne fut diagnostiquée dans le groupe REC.

On en conclut que l'utilisation des médicaments très actifs contre la lèpre en association et suivant la posologie appropriées permet de réduire de 3 mois la durée du traitement antibactérien en cas de lèpre multibacillaire.

\section{El tratamiento de la lepra multibacilar con un regimen de 13 semanas}

\author{
S R Pattyn, G Groenen, L Janssens, L Kuykens y L B Mputu
}

Resumen En un estudio eventual, se trataron 559 pacientes multibacilares en Zaires por 13 semanas rifampicina $(600 \mathrm{mg}$ ) dos veces por semana y dosis diarias de etionamida (500 mg) y dapsona (100 mg), 13-RED, o de clofazimina $(100 \mathrm{mg}), 13-\mathrm{REC}$. Se controlaron los pacientes por un tiempo total de 1418 personas-año, con un promedio de 3,2 años. La incidencia de recaídas fue 0,28 por cada 100 personas-año. Las recaídas se debían a organismos sensibles a las drogas.

En los parcientes que recibieron los mismos regimenes de drogas, pero con una dosis reducida de etionamida de $5 \mathrm{mg} / \mathrm{kg}$ de peso, la incidencia de hepatitis fue significativamente inferior, pero la tasa de recaída era 7,8 por 100 persona-año en la continuación de estudio del grupo RED, mientras que no hubieron recaídas en el grupo REC.

La conclusion fue que, usando potentes drogas antileprosas en combinaciones y dosis adecuadas, era posible reducir la duración del tratamiento antibacteriano en la lepra multibacilar a un período de 3 meses. 